\title{
PROCESS PRODUCTION OF BIODIESEL USING A MINI PLANT
}

\author{
Yoel Pasae ${ }^{1} \bowtie$, Medris Ranak ${ }^{2}$, Lyse Bulo ${ }^{3}$, Eda Lolo Allo ${ }^{4}$, Liberthin Palullungan ${ }^{5}$, Petrus ${ }^{6}$ \\ 1, 2,3 Department of Chemical Engineering Universitas Kristen Indonesia Paulus, Indonesia. \\ ${ }^{4}$ Chemistry Department, Faculty of Match and Science, Universitas Negeri Makassar, Indonesia. \\ ${ }^{5}$ Department of Law Universitas Kristen Indonesia Paulus, Indonesia. \\ ${ }^{6}$ Department of Management Universitas Kristen Indonesia Paulus, Indonesia.
}

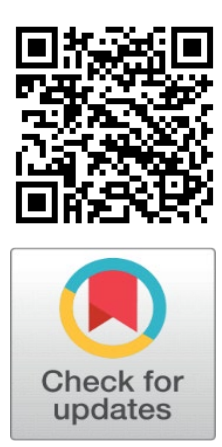

Received 5 November 2021

Accepted 16 December 2021

Published 31 December 2021

CorrespondingAuthor

Yoel Pasae,

ypasae@ukipaulus.ac.id

DOI

10.29121/granthaalayah.v9.i12.2021 4429

Funding: This research received no specific grant from any funding agency in the public, commercial, or not-for-profit sectors.

Copyright: (C) 2021 The Author(s). This is an open access article distributed under the terms of the Creative Commons Attribution License, which permits unrestricted use, distribution, and reproduction in any medium, provided the original author and source are credited.

\section{ABSTRACT}

Biodiesel is a type of alternative fuel to replace diesel. Refined Bleached Deodorized Palm Oil (RBDPO) is a raw material that has the potential to be processed into biodiesel because of its abundant availability and easy to obtain. The focus of this research is to carry out the biodiesel production process using a mini biodiesel plant with a capacity of 50 liters/batch, and the catalyst used is $\mathrm{NaOH}$. The results showed that the portable factory can produce biodiesel with a yield of $90.86 \%$. The characteristics of the biodiesel produced were analyzed and the following values were obtained: density $0.89 \mathrm{~g} / \mathrm{mL}$, viscosity $4.69 \mathrm{CSt}$, acid number $1.68 \mathrm{mg} \mathrm{KOH} / \mathrm{g}$, and saponification number $179.52 \mathrm{mg}$ $\mathrm{KOH} / \mathrm{g}$.

Keywords: Biodiesel, RBDPO, Portable Biodiesel Plant

\section{INTRODUCTION}

The oil crisis and global warming have caused research to be oriented to find suitable alternative fuels for petroleum. Currently, biodiesel is produced from non-vegetable vegetable oil because of the high cost of vegetable oil which makes the environment an alternative fuel to replace diesel oil Abed et al. (2018). Biodiesel is a type of alternative fuel to replace diesel. The use of biodiesel as an alternative fuel for petro-diesel has a positive impact on increasing fossil energy reserves, reducing gas emissions that can pollute the environment, waste products from combustion are easily degraded and can be renewed. The results of various research studies conclude that biodiesel can be produced from various types of vegetable oils such as jatropha, kepo oil, used cooking oil, coconut, palm oil, corn oil, soybean oil and animal fat oils.

As a renewable resource, palm oil is one of the potential raw materials for biodiesel production because it is cheap and has the highest yield per hectare compared to all vegetable oil feedstocks Dujjanutat and Kaewkannetra (2020).

Transesterification is an ester formation reaction with the help of an acid, base or enzyme catalyst from triglycerides. Transesterification reaction catalysts are compounds derived from alkaline group elements such as $\mathrm{NaOH}, \mathrm{KOH}$, $\mathrm{CH}_{3} \mathrm{ONa}$ and $\mathrm{CH}_{3} \mathrm{OK}$ which provide high conversion and reaction rates Atadashi (2014). The transesterification reaction between triglycerides and methanol produces a mixture consisting of biodiesel, components of impurities such as soap, catalyst, glycerol, residual methanol and unreacted triglycerides.

Several studies that have evaluated the results of biodiesel purification using the raw material in the form of $5 \mathrm{~L}$ palm oil bulk (small capacity) from previous 
experiments, concluded that biodiesel is influenced by acid number and saponification number. The optimal results from each experiment they carried out produced biodiesel products with characteristics that had different yield values for saponification numbers and acid numbers, some of which were included in the range of the Indonesian National Standard.

In this study, bulk palm oil in a large capacity of 50 liters/batch of portable biodiesel will be used. As for the formulation of the problem, how is biodiesel productivity from palm bulk oil using a portable biodiesel plant? What are the characteristics of biodiesel produced from palm oil bulk?

\section{METHODS}

$39,840 \mathrm{~mL}$ of bulk palm oil is fed into the reactor. $\mathrm{NaOH}$ catalyst as much as $17.930 \mathrm{~g}$ of oil mass is mixed into $10.160 \mathrm{~mL}$ of methanol, stir until a homogeneous solution and mix with oil into the reactor. The oil and mixture of $\mathrm{NaOH}$ catalyst with methanol in the reactor is heated at $50^{\circ} \mathrm{C}$ for 10 minutes, the reaction transesterification takes place at an operating temperature of $60^{\circ} \mathrm{C}$ and a reaction time of 2 hours Salla (2019) . During the reaction, stirring is carried out and the temperature of the reactants is controlled using a temperature controller. Evaporation of unreacted methanol was carried out by increasing the reactor temperature to $80^{\circ} \mathrm{C}$ for 1 hour. After the evaporation process, the temperature is lowered to $30^{\circ} \mathrm{C}$, after 10 minutes it is lowered to $0^{\circ} \mathrm{C}$ and the appliance is turned off. Then it was cooled for 2 hours.

The mixture is flowed into a separator tank, then allowed to separate to form a layer of methyl ester and glycerol. The phase rich in methyl ester components will be on the top and the phase rich in glycerol components will be on the bottom layer which then the glycerol component will be removed from the separator tank. Wash the methyl ester component using distilled water in the reactor. The mixture is stirred until the methyl ester is neutral. After obtaining the methyl ester, then the methyl ester is put into the evaporation tank and evaporated for 4 hours to remove the remaining water content. Biodiesel is weighed and the yield is calculated.

The characterization of raw materials was carried out to determine the water content, free fatty acid content, acid number, saponification number, viscosity and density in the oil before the tanesterification process, referring to SNI 04-71822015 .

\section{RESULT AND DISCUSSION}

Table 1. below presents data on the characteristics of raw materials for Refined Bleach Deodorized Palm Oil (RBDPO)

\begin{tabular}{|ccc|}
\hline \multicolumn{3}{|c}{ Table 1 Characteristics of Raw Material } \\
\hline No & Phisycochemical Properties & Value \\
1 & Water content (\% mass) & 0.02 \\
\hline 2 & FFA (\% mass) & 3.73 \\
3 & Acid number (mg KOH/g) & 2.8 \\
\hline 4 & Saponification number (mg KOH/g) & 206.44 \\
\hline 5 & Cinematic Viskosity (sCt) & 28.88 \\
\hline 6 & Density (g/mL) & 0.9 \\
\hline
\end{tabular}


From Table 1, the results of the analysis of the water content in the oil are $0.02 \%$ and the FFA content is $3.73 \%$. The desired water content standard for the transesterification process is $<0.5 \%$ (SNI 2015) and FFA $<2 \%$ Dan et al. (2011). So based on this standard, the biodiesel synthesis process from RBDPO (Refined Bleach Deodorized Palm Oil) has a high FFA value caused by late processing of fruit due to delayed transportation, injuries to oil palm bolts due to rough handling, low oil yield due to poor fruit quality. poor and lost crops, (Pyro Adi Lukito, 2017).

\begin{tabular}{|c|c|c|c|c|c|}
\hline \multicolumn{6}{|c|}{ Table 2 Result of Production Biodiesel } \\
\hline Run & RBDPO (mL) & Methanol (mL) & Catalyst (g) & Biodiesel (mL) & Glycerol (mL) \\
\hline I & 19.92 & 5.08 & 358,605 & 18.1 & 1.9 \\
\hline II & 19.92 & 5.08 & 358,605 & 4.865 & 1.89 \\
\hline III & 39.84 & 10.16 & 17,930 & 33450 & 4.1 \\
\hline
\end{tabular}

From Table 2, it is concluded that the volume of oil varies in run I and II, the volume of palm oil bulk is the same, namely $19,920 \mathrm{~mL}$. However, in run II there was a decrease in biodiesel yield of $4.865 \mathrm{~mL}$ due to the washing process in the reactor with moderately strong stirring and 30 minutes of stirring which was too long, resulting in the formation of more soap than biodiesel, run I with 5 minutes of stirring. Then the volume of palm bulk oil was increased to $39,840 \mathrm{~mL}$ with the catalyst being reduced by $0.05 \%$ of the volume of palm oil bulk because in the second run it produced more soap than biodiesel and the stirring time was 5 minutes.

Compliance with standards is very important whether or not the product is worthy of being marketed Winalda et al. (2018). The results of the analysis are then compared with the standards that have been set by SNI. The analysis carried out includes density, viscosity, acid number, and saponification number, and water content. The selection of these parameters is selected for characteristic variables that do not cost much. The characteristics of biodiesel according to SNI can be seen in Figure 1, 2, 3, 4 and Figure 5.

Density is the ratio of the weight of a sample volume to the weight of water at the same volume and temperature.

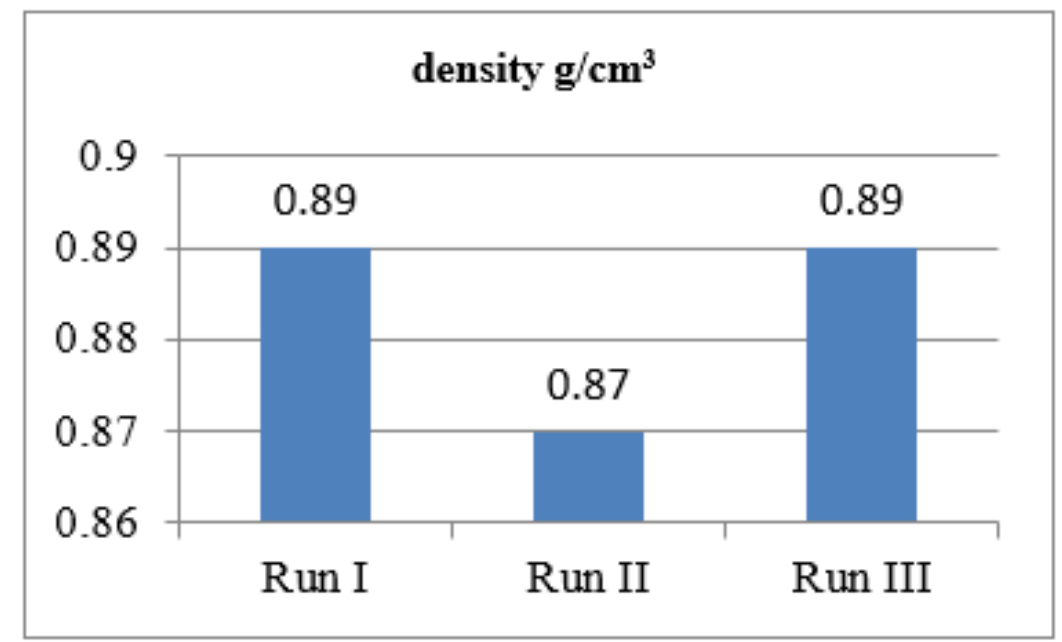

Figure 1 Density of biodiesel 
Based on the data in Figure 1, it is known that the density is in the range of values required by the Indonesian National Standard (SNI), where the density standard for biodiesel is $0.85-0.89 \mathrm{~g} / \mathrm{cm}^{3}$.

Viscosity is a function of time of a liquid flowing through a capillary under the influence of Earth's gravity which is expressed in centiskotes (cSt).

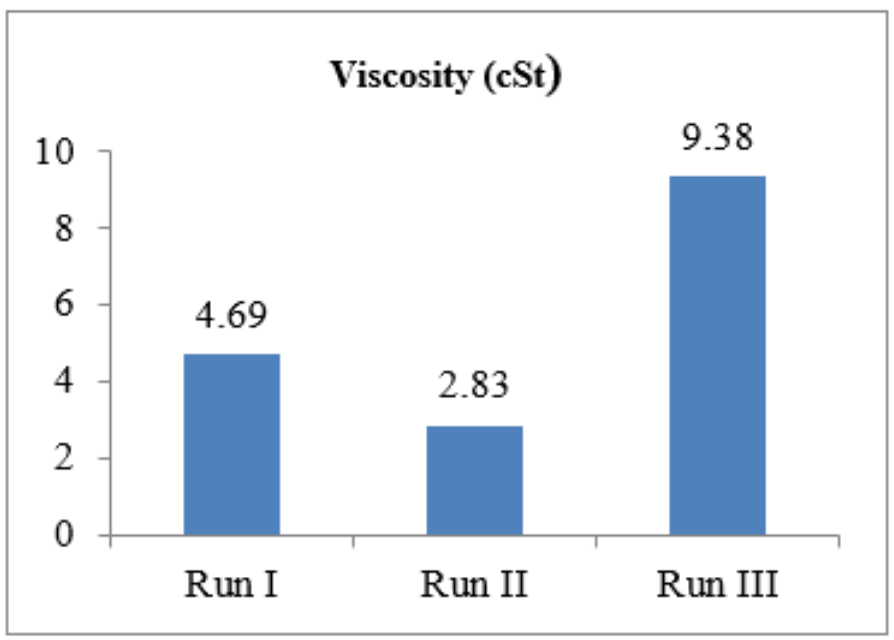

Figure 2 Viscosity of biodiesel

Biodiesel viscosity analysis was carried out using an Oswald Viscometer. Figure 2 shows that biodiesel viscosity varies, when compared to biodiesel specifications based on SNI where the standard is 2.3-6.0. Biodiesel obtained in Run I and II meets the Indonesian National Standard, while Run III is not included in the Indonesian National Standard. Factors that affect viscosity are caused by unreacted triglycerides in the product, glycerin contamination and the composition of its constituent fatty acids Andriani (2020)

Acid number is the amount of free fatty acids in biodiesel samples. The quality of biodiesel is very influential on the acid number. Determination of the acid number is carried out by standard analytical methods for acid number.

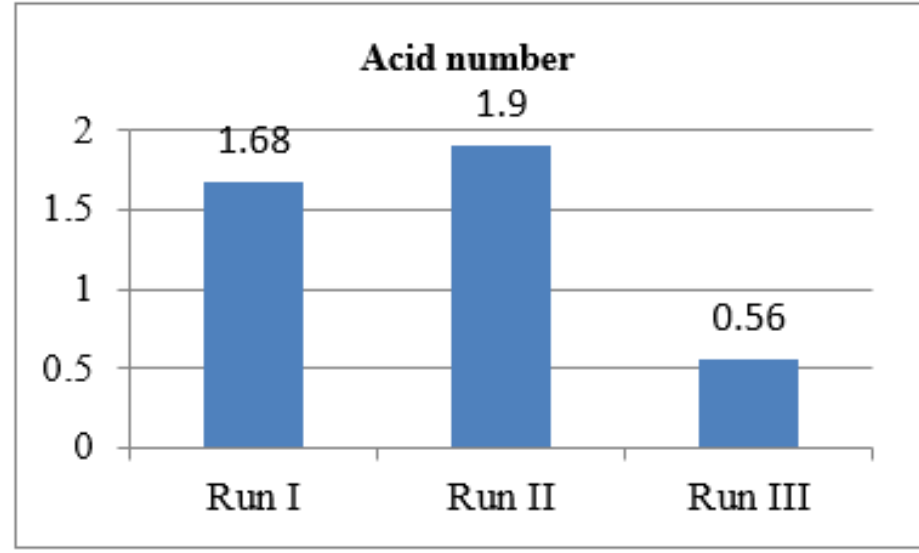

Figure 3 Acid number of biodiesel

Based on Figure 3, it can be seen that the acid numbers in Run I and Run II were higher while Run III met the SNI requirements. High acid values in biodiesel can 
cause deposits in the combustion system and also indicators of acid containing corrosion, causing damage to the engine.

The saponification number is mg of $\mathrm{KOH}$ which is used to saponify $1 \mathrm{~g}$ of the sample. Determination of the number of saponification in order to determine the nature of fats and oils that distinguish fats from other fats. At each run, the value of the saponification number decreases.

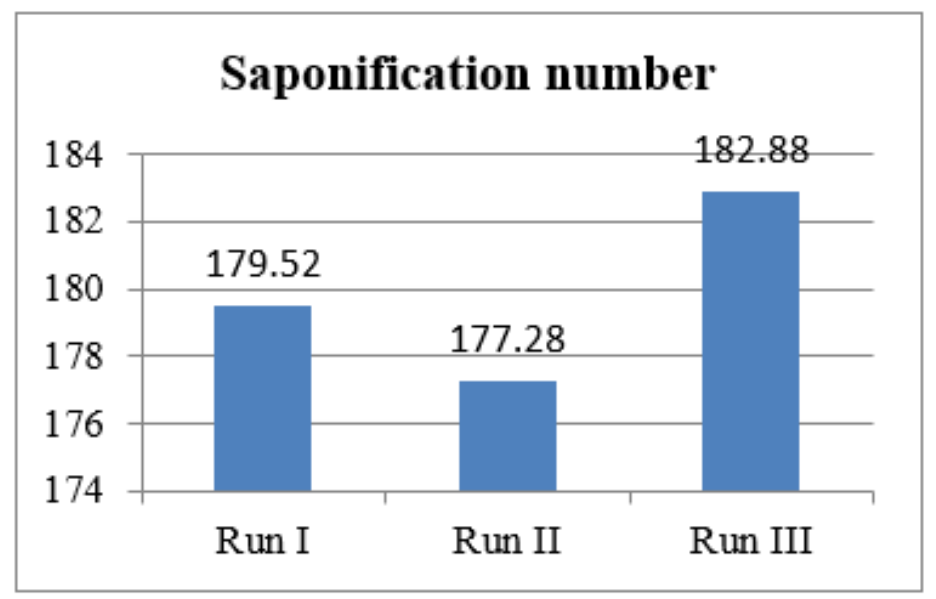

Figure 4 Saponification number of biodiesel

Figure 4 shows that the amount of saponification in biodiesel meets SNI in run I and run III, while run II does not meet SNI. The high saponification number depends on the molecular weight of the fat, the lower the molecular weight the higher the saponification number Yanti (2019).

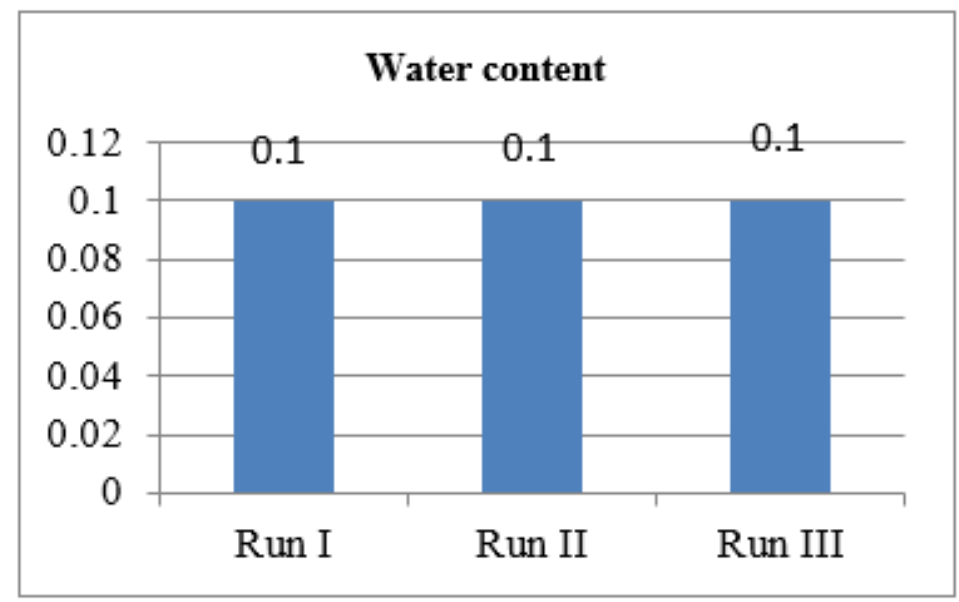

Figure 5 Water content of biodiesel

Water content is the amount of water contained in an object. Figure 5 shows that the water content in biodiesel products from Run I, II, and III is $0.1 \%$. This value meets the requirements of SNI. 


\section{CONCLUSION}

1) The biodiesel production process from RBDPO has been carried out in a mini biodiesel plant. The highest biodiesel yield was obtained in run I with a value of $90.86 \%$.

2) The characteristics of the biodiesel produced were analyzed and the following values were obtained: density $0.89 \mathrm{~g} / \mathrm{mL}$, viscosity $4.69 \mathrm{CSt}$, acid number $1.68 \mathrm{mg} \mathrm{KOH} / \mathrm{g}$, and saponification number $179.52 \mathrm{mg}$ $\mathrm{KOH} / \mathrm{g}$.

\section{ACKNOWLEDGMENT}

We would like to thank the Directorate General of Higher Education, Research and Technology, Ministry of Education, Culture, Research and Technology, which has funded this research through the Grant Fund for the Independent Learning Policy Research Program at the Independent Campus and Community Service Based on PTS Research Results in 2021.

\section{REFERENCES}

Abed, K. A., Morsi, A. K. El, Sayed, M. M., Shaib, A. A. El, \& Gad, M. S. (2018). Effect Of Waste Cooking-Oil Biodiesel On Performance And Exhaust Emissions Of A Diesel Engine. Egyptian Journal of Petroleum, 27(4), 985-989. Retrieved from https://doi.org/10.1016/j.ejpe.2018.02.008

Andriani, M. (2020). Kajian variasi suhu pada proses produksi biodiesel secara katalitik dengan menggunakan static mixing reactor. Retrieved from https://repositori.usu.ac.id/handle/123456789/26986

Atadashi, I. M. (2014). Removal of residual palm oil-based biodiesel catalyst using membrane ultra-filtration technique: An optimization study. Alexandria Engineering Journal, 53(3), 705-715. Retrieved from https://doi.org/10.1016/j.aej.2014.07.002

Chyuan, H., \& Silitonga, A. S. (2020). Patent landscape review on biodiesel production: Technology updates. Renewable and Sustainable Energy Reviews, 118(April 2019), 109526. Retrieved from https://doi.org/10.1016/j.rser.2019.109526

Dan, P., Kualitas, U. J. I., \& Dari, B. (2011). Fakultas Sains Dan Teknologi Universitas Islam Negeri (Uin) Alauddin Makassar.

Dujjanutat, P., \& Kaewkannetra, P. (2020). Production of bio-hydrogenated kerosene by catalytic hydrocracking from re fi ned bleached deodorised palm / palm kernel oils. Renewable Energy, 147, 464-472. Retrieved from https://doi.org/10.1016/j.renene.2019.09.015

Dyah, S., \& Sukaryo, P. (2018). Uji Karakteristik Biodiesel Berbahan Dasar Limbah Jeroan Ikan Diproses Menggunakan Mikrogelombang. 14(2), 37-42. Retrieved from https://doi.org/10.14710/metana.v14i2.20333

Efavi, J. K., Kanbogtah, D., Apalangya, V., Nyankson, E., Tiburu, E. K., Dodoo-arhin, D., Onwona-agyeman, B., \& Yaya, A. (2018). South African Journal of Chemical Engineering The effect of $\mathrm{NaOH}$ catalyst concentration and extraction time on the yield and properties of Citrullus vulgaris seed oil as a potential biodiesel feed stock. South African Journal of Chemical Engineering, 25, 98102. Retrieved from https://doi.org/10.1016/j.sajce.2018.03.002 
Holser, R. A. (2007). Short communication Transesterification of epoxidized soybean oil to prepare epoxy methyl esters $\approx .7,130-132$. Retrieved from https://doi.org/10.1016/j.indcrop.2007.06.001

Internasional Biodisel Workshop. (2001).

Kepdirjen EBTKE tentang (2019). Standar dan Mutu BBN Jenis Biodiesel sebagai Bahan Bakar Lain yang Dipasarkan di Dalam Negeri .pdf. (N.d.).

Pasae, Y. (2017). The Effect Of Blending Branched Fatty Acid Ester With Biodiesel Towards Physical Properties, Engine. 12(17), 5104-5108.

Pasae, Y., Leste, J., Bulo, L., Tandiseno, T., \& Tikupadang, K. (2019). Biodiesel Production From Waste Cooking Oil With Catalysts From Clamshell. 14(3), 2006-2009.

Pasae, Y., Tangdilintin, S., Bulo, L., \& Allo, E. L. (2020). The Contribution Of Heterogeneous And Homogeneous Catalysts Towards Biodiesel Quality The Contribution Of Heterogeneous And Homogeneous Catalysts Towards Biodiesel Quality. 3(10). Retrieved from https://doi.org/10.1088/17426596/1464/1/012054

Rafati, A., Tahvildari, K., \& Nozari, M. (2018). Production of biodiesel by electrolysis method from waste cooking oil using heterogeneous $\mathrm{MgO}-\mathrm{NaOH}$ nano catalyst Energy Sources, Part A : Recovery, Utilization, and Production of biodiesel by electrolysis method from waste cooking oil using heterogeneous MgO- NaOH nano catalyst Atlas Rafati, Kambiz Tahvildari \& Maryam Nozari. Energy Sources, Part A : Recovery, Utilization, and Environmental Effects, 00(00), 1-13. Retrieved from https://doi.org/10.1080/15567036.2018.1539139

Salla, Y. (2019). Purifikasi Biodisel Dari Minyak Curah Kelapa Sawit (Refined Bleached Deodorized Palm Oil) Menggunakan Teknologi Pemisahan Membran.

Series, I. O. P. C., \& Science, M. (2020). Transesterification of refined bleached deodorized palm oil (rbdpo) using novozym ${ }^{\circledR} 435$ to produce biodiesel Transesterification of refined bleached deodorized palm oil (rbdpo ) using novozym ® 435 to produce biodiesel. Retrieved from https://doi.org/10.1088/1757-899X/796/1/012056

Stoytcheva, M. (2011). Quality, Emissions And By-Products. Edited by Gisela Montero (Issue November).

Winalda, A. R., Tanjung, M. N., \& Purwaningsih, I. S. (2018). Studi empiris karakteristik biodiesel berdasarkan komposisi asam lemak bahan baku. 3540.

Yanti. (2019). Pengujian Proses Reactive Separation Kapasitas 5 Liter/Batch Untuk Produksi Biodisel Dari Minyak Sawit Curah Berkatalis NaOH Dan CaO Super Basa.

Zahrina, I., \& Akbar, F. (2012). Perengkahan PFAD (Palm Fatty Acid Distillate) Dengan Katalis Zeolit Sintesis Untuk Menghasilkan Biofuel. 9(1), 45-50 